\begin{tabular}{l|c|c}
\hline $\begin{array}{l}\text { ISSN: 0001-5113 } \\
\text { AADRAY }\end{array}$ & ACTA ADRIAT., & ORIGINAL SCIENTIFIC PAPER \\
\hline \hline
\end{tabular}

\title{
Temperature constraints shaped the migration routes of mackerel (Scomber scombrus) in the Black Sea
}

\author{
Daniel PAULY ${ }^{1} \&$ Çetin KESKIN ${ }^{2 *}$ \\ ${ }^{1}$ Sea Around Us, Institute for the Oceans and Fisheries, 2202 Main Mall, \\ University of British Columbia, BC, Canada, V6T $1 Z 4$ \\ ${ }^{2 *}$ Faculty of Fisheries, University of Istanbul, Ordu St. No: 200, \\ 34470 Laleli, İstanbul/Turkey
}

${ }^{*}$ Corresponding author, e-mail: seahorse@istanbul.edu.tr

Conventional narratives explain fish migrations in term of requirements (food, mates, habitats, etc.), with adequate temperatures being optional. Here, using the example of a (commercially extinct) stock of Black Sea mackerel (Scomber scombrus), we suggest that seasonal migrations are driven by seasonal temperature cycles. Therein, temperature acts as a constraint determining where the fish can be at any given time, and not a one of several factors which they would consider when choosing between alternative migration routes. Generalizing, we suggest that temperature should generally be an explicit part of hypotheses about the migratory behaviours of marine fishes. For illustration of what may occur when this is not the case, it is suggested that the non-consideration of temperature in a model of North Atlantic mackerel migration may have led, among the researchers concerned, to a sense of complacency with respect to the climate change-induced changes in the phenology of this fish in the North Atlantic, whose distribution and migration are misleadingly seen as "stochastic".

Key words: fish, global warming, distribution, oxygen requirement

\section{INTRODUCTION}

Migrations are a well-known feature of fishes, used for millennia by fishers to plan their operations in space and time (SARHAGE \& LUNDBECK, 1992). Fish migrations are also of great scientific interest and they have spawned an extensive literature (see, e.g., HARDEN-JONES, 1968).

One feature of this historical literature is that much of their descriptions and/or explanations of fish migrations is that it projects onto fishes many of "our inherent terrestrial-mammalian evolved capacities and inclinations" (BAKUN, 2011), which that cause us to interpret the behaviours of fishes as if they were mammals like us.

Thus, HEAPE (1931), surveying all animal groups suggested "alimental migrations" for food (and water, in terrestrial animals); "climatic migrations", for appropriate environmental conditions; and "gametic migrations", for reproduction, a classification also adopted by HARDEN- 
JONES (1968) and which has not much changed since (see, e.g., ROSE, 1993), except perhaps that "stochastic migrations" have been added (HANNESON, 2012).

With global warming shaping fish communities worldwide (CHEUNG et al., 2013), however, the time has come to suggest another view of migration, which we suggest should be centred on the extreme sensibility of their oxygen metabolism to temperature (Fig. 1; PAULY 1998; 2010).

While specialized tropical and (non-diadromous) polar fishes have relatively narrow thermal niches, of $2-5{ }^{\circ} \mathrm{C}$, subtropical and especially temperate fishes have wide thermal niches, i.e., of about $10{ }^{\circ} \mathrm{C}$ (CHEUNG et al., 2013), which also applies if one uses their ability to maintain positive growth rates as a criterion (PAULY, 2010). However, coastal waters, particularly in marginal seas such as the Black Sea, while providing potential habitat and abundant food sources, have water temperatures whose seasonal oscillations exceed $10^{\circ} \mathrm{C}$, often by far, and whose mean annual temperature is below the preferred temperature of several of its commercial fish species.

Such water body can be utilised by migrating fish only when and where the temperature is appropriate. If those appropriate place and time also provide good feeding opportunities, the population in question will thrive, otherwise, it will not. This mechanism is best illustrated by the climate-warming induced poleward shifts in the distribution of various fish species (PERRY et al., 2005; CHEUNG et al., 2009). The fish involved therein do not select between various combinations of suitable temperature and food availability. Rather, they are driven by temperature, and have to make do with the quantity and type of food organisms they find at their new locations (CHEUNG et al., 2011). This, ultimately, is the reason why global fisheries yields are expected to decline under global warming (CHEUNG et al., 2010).

We illustrate this manner of interpreting information on fish migration using the example of mackerel (Scomber scombrus) in the Black Sea, i.e., a stock that does not seem to exist anymore, following the overfishing of their spawning concentrations in the Marmara Sea (IVANOV \& BEVERTON, 1985; ULMAN \& PAULY, 2016). Their annual migrations into the Black Sea was described in classical fashion by GALTSOFF (1924), using conventional terminology (e.g., "summer feeding grounds", "overwintering", etc.), with temperature mentioned only casually. In contrast, we suggest that the entire migration cycle of mackerel in the Black Sea was driven by temperature, and that an alternative view of this migration (and by extension that of other fishes) will help us better understand fish migrations in the age of ocean warming.

\section{MATERIALS AND METHODS}

We show that mackerel have gills which, as expected, cannot keep up with their somatic growth by plotting the gill area of five specimens, as estimated by HUGHES (1966; see also www. fishbase.org), against their body weight, ranging from 226 to $1000 \mathrm{~g}$. Here, the expected slope of a double-logarithmic plot is 0.75 to 0.80 (PAULY, 1981; 2010), implying a marked decline of gill area (and hence oxygen delivery) per unit body weight as weight increases. Consequently, the maximum size that can be reached should be an inverse function of oxygen requirements, which increase with temperature (PAULY, 1998; 2010).

We then combined the information in Fig. 1 of GALTSOFF (1924) with the description in DEMIR \& ACARA (1955) to generate maps of the (spring) migration of mackerel into the Black Sea and of the (fall) migration out of the Black Sea into the Bosphorus and the Marmara Sea, where mackerel 'overwinter'.

The mean monthly sea surface temperatures (SST) from 1910 to 1919 at the approximate location of the migrating mackerel were extracted by 1 degree latitude x 1 degree longitude from the COBE-SST2 data, provided by the NOAA/OAR/ESRL PSD, Boulder, Colorado, USA (http://www.esrl.noaa.gov/psd/). SSTs from the 1910s we were used to account for the fact that the map of GALTSOFF (1924) probably referred to migrations routes that occurred, in the Black Sea in the second decade of the $20^{\text {th }}$ 

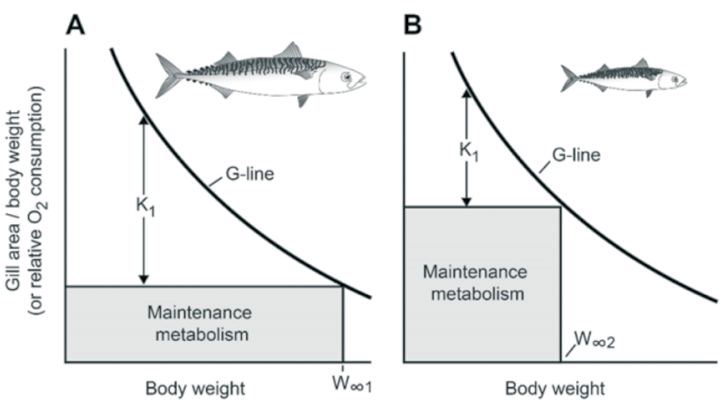

Fig. 1. Diagram illustrating how maintenance metabolism, and hence temperature, determines asymptotic weight $\left(W_{\infty}\right)$, given a certain G-line (defined by gill area growth relative to body weight growth) because, at $W_{\infty}$, relative gill area (and hence oxygen supply) is just enough for maintenance (shaded area); A. Fish exposed to a low level of stress (e.g., relatively low temperature, abundant oxygen, abundant food). $\boldsymbol{B}$. Fish exposed to a higher level of stress (low oxgen concentration, high temperature, causing rapid denaturation of body protein, and/or low food density, requiring $\mathrm{O}_{2}$ to be diverted to foraging, rather than protein synthesis). This explains why temperature is so important for fishes, and why the fish of a given species attain different lengths at different latitudes, i.e., temperatures (see also PAULY, 1981; 1984; 2010)

century. Also, the annual cycle of mean monthly SST was recorded for each of the Black Sea locations defining the monthly migration of mackerel (see letters B to Q in Fig. 3).

The temperature at depth between 30 and $120 \mathrm{~m}$ in the Bosphorus (including its opening to the Black Sea) and in the Marmara Sea was set at $14.5{ }^{\circ} \mathrm{C}$ throughout the year, following DEMIR \& ACARA (1955, p. 368 and PEKTAS 1954; see also GREGG \& ŐZSOY 2002).

\section{RESULTS AND DISCUSSION}

Fig. 2 presents the plots of body weight (W, in $\mathrm{g})$ vs. gill area $\left(\mathrm{G}\right.$; in $\left.\mathrm{cm}^{2}\right)$ in $S$. scombrus, with can be described by the relationship log $(\mathrm{G})=1.43+0.733 \cdot \log (\mathrm{W})$, with the $95 \%$ confidence interval of the slope ranging from 0.613 to 0.853 . This slope being lower than unity implies a relationship between gill area (and hence oxygen supply) per body weight declining with body weight as shown in the two panels of Fig. 1 Note also that this slope being lower than unity applies only to fish past metamorphosis;

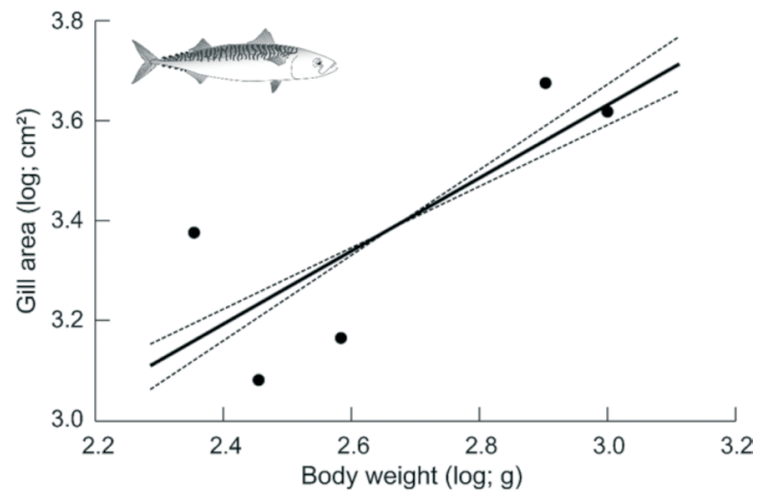

Fig. 2. Gill surface area vs. body weight in 5 individual mackerel (Scomber scombrus), illustrating that mackerel, like all other fishes, has respiratory areas that increase with body size, but this growth does not keep up with weight, i.e., the slope of the log-log plot is $<1$ (see Fig. 1 and text for implication). Based on data on HUGHES (1966) as reported in FishBase

the metabolism of larval fish is generally proportional to their body weight (BOCHDANSKY \& LEGGETT, 2001; PAULY, 2010), and mackerel larvae are no exception (CIGUÈRE et al., 1980).

In the Fig. 3 is presented our re-interpretation of the annual migrations of mackerel into (Fig. 3A) and out (Fig. 3B) of the Black Sea, respectively, in the first half of the $20^{\text {th }}$ century.

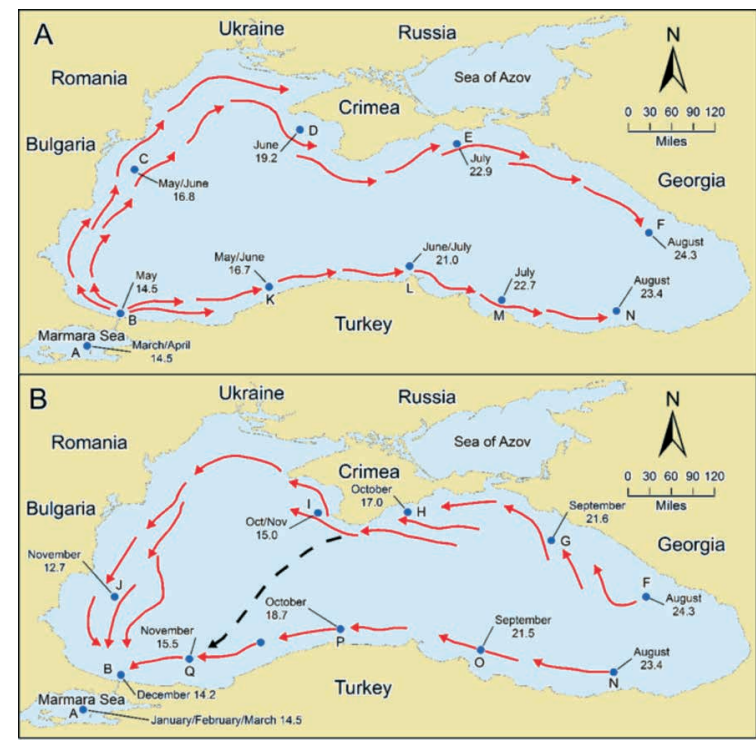

Fig. 3. Former migration routes of mackerel (Scomber scombrus) into the Black Sea (as inferred from GALTSOFF, 1924), from late March to early August (A) and return migration into the Marmara Sea from late August to December (B). The mean SST in the months when mackerel were present in various areas (points $A-Q)$ is also indicated 


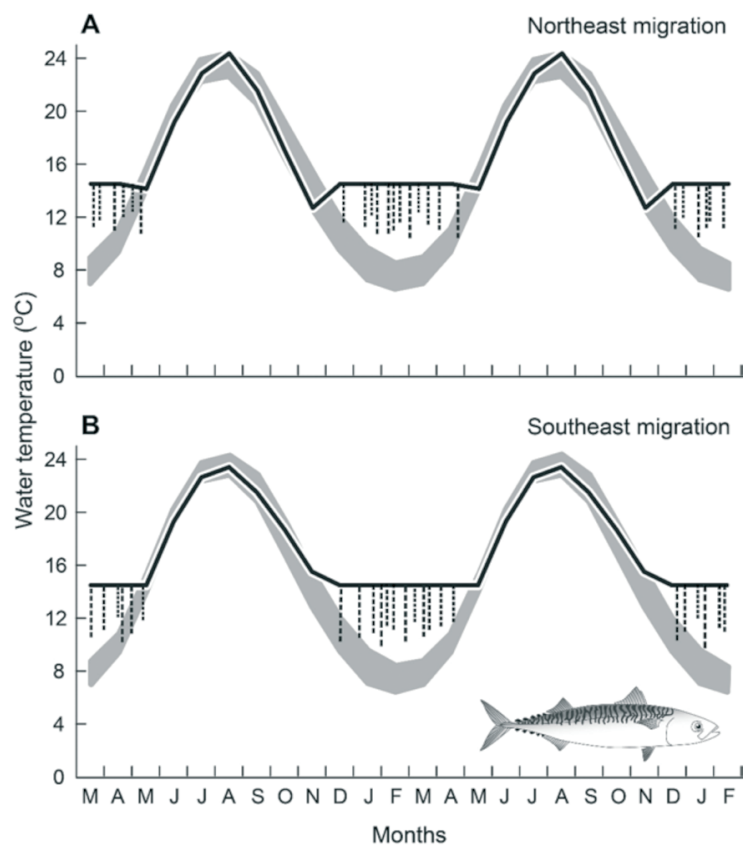

Fig. 4. Annual fluctuations of SST at points of the Black Sea (indicated by the letters $C-Q$ on Fig. $3 A$ and $3 B$ ) which mackerel passed by in their annual migration, contrasted with the annual temperature fluctuations experienced by migrating mackerel, including the near constant temperature of the deeper Marmara Sea and Bosporus. Dotted vertical lines indicate brief feeding forays into the colder surface waters of the Marmara Sea (see text)

Note that the Southeast migration route (along the Turkish coast) was taken only by a small fraction of the mackerel pouring out of the Bosphorus in the spring, the Northern route being much preferred (DEMIR \& ACARA, 1955). Also, in the fall, the Northern route was shortened for the return migration, when temperatures were falling too quickly as the mackerels returned directly from the area around the Crimea to the Bosporus (dotted black line on Fig. 3B; see also Fig. 1 in GALTSOFF, 1924). Thus, the return migration of mackerel probably did not include point $\mathrm{J}$ in Fig. 3B in November, when the SST in its vicinity was 12.7 , as it was in the average for 1910-1919.

The Fig. 4 illustrates that the migration routes of mackerel between and within the Black Sea and the Marmara Sea enabled the fish to maintain themselves at temperature exceeding $14{ }^{\circ} \mathrm{C}$ throughout the year, although they sometime made quick daily forays into colder surface water $\left(10-12{ }^{\circ} \mathrm{C}\right)$ while in the Marmara Sea, to feed on abundant zooplankton (DEMIR \& ACARA, 1955; NALBANTOGLU, 1957).

This implies that the population of $S$. scombrus that migrated between the Marmara Sea and Black Sea was adapted to warmer temperatures (mean $17^{\circ} \mathrm{C}$ ) than most other populations of this species, whose overall distribution suggests a 12 ${ }^{\circ} \mathrm{C}$ as preferred temperature (CHEUNG et al., 2013, Table S1). Table 1 document the implications of this difference in terms of Fig. 1, i.e. as a smaller asymptotic size. Further evidence that the Marmara/Black Sea mackerel performed migration entirely driven by temperature is provided by the observation that when SSTs were high, they spawned in the Black Sea, often quite far from the mouth of the Bosporus, in spite of the fact that the low salinity of the Black Sea was inimical to the development of their eggs (DEMIR \& ACARA, 1955; DEMIR \& ARIM, 1957). Indeed, NÜMANN (1957) suggested that mackerel spawning in the Black Sea, which led to massive egg deaths, might be the reason why fishery yields tented to be low following years with high SST.

Turkish researchers were well aware of the key role of temperature in shaping fish migration across the Bosporus (and the Dardanelles), notably because bonito (Sarda sarda) and a host of other species migrate between the Black Sea and the Aegean Sea in a manner resembling that described here for S. scombrus (see e.g., DEMIR, 1957; 1963). Yet their insights about the structuring role of temperature for migrations (now being rediscovered, e.g. by JANSEN \& GISLASON, 2011), did not take.

Thus, for example D'AMOURS \& CASTONGAY (1992), based on occasional high catches below the preferred temperature of Gulf of St. Lawrence mackerel wrote that "previous evidence from which the role of temperature on the migration of mackerel has been inferred, is circumstantial" and that "the movements of mackerel are not as closely linked to water temperature as previously reported. The fish's thermal preferences could be subordinate to their reproductive requirements at this stage of their spawning migration". However, these general conclusions may not apply, as they were derived 
Table 1. Comparison of growth parameters of stocks of mackerel (Scomber scombrus) from different temperature regimes, the Northeast Atlantic and in the Marmara Sea, Bosphorus and Black Sea

\begin{tabular}{l|c|c|l}
\hline $\begin{array}{l}\text { Stocks (Mean of temperature encountered } \\
\text { by mackerels) }\end{array}$ & FL $\infty \mathbf{( c m )}$ & K (year) & Sources; remarks \\
\hline $\begin{array}{l}\text { Several, North Atlantic } \\
\left(10-14^{\circ} \mathrm{C}\right)^{\mathrm{a}}\end{array}$ & 43 & 0.27 & $\begin{array}{l}\text { VILLAMOR } \text { et al. (2004); } \\
\text { mean of several } \\
\text { growth curves }\end{array}$ \\
\hline $\begin{array}{l}\text { Marmara Sea, Bosphorus and Back Sea ( } \\
\left.16-18^{\circ} \mathrm{C}\right)^{\mathrm{b}}\end{array}$ & 27 & 0.40 & $\begin{array}{l}\text { IVANOV \& BEVERTON } \\
\text { stock density regimes }\end{array}$ \\
\hline
\end{tabular}

a Based on mackerel distribution in the North Atlantic, using temperatures from the Hadley Centre SST data set for 1970-2000; see CHEUNG et al. (2013).

${ }^{\mathrm{b}}$ Based on COBE-SST2 data for 1910-1919; see also Fig. 4.

from fish that appear to have been making quick feeding forays into colder water (WALSH et al., 1995), as also reported for mackerel in the Marmara Sea and Bosporus (Fig. 4).

Another example is NØTTESTAD et al. (1999), who present a "length-based hypothesis for feeding migration in pelagic fishes" (including mackerel) which does not include temperature among its 30 + parameters, eventhough the bioenergetic considerations upon which the model is based are all exquisity dependant on temperature.

This leads to complex ad hoc hypotheses, such as the correlation between maximum sizes of 4 species of fish being related to latitude (see Fig. 6 in NØTTESTAD et al., 1999), i.e. to longer summer days at high latitude providing more opportunities for feeding. In contrast, the obvious hypothesis that the lower temperatures of high latitudes provide the explanation for the larger fish size (as shown in the Fig. 1) was not even examined.

A consequence of this omission of temperature is that the model of NØTTESTAD et al. (1999) cannot be used to throw light on the changes in the distribution and migration of North Atlantic mackerel, which, possibly as a result, HANNESSON (2012) labels as 'random' and 'stochastic'.
This is another way of stating that he doesn't know what drives these changes, and not unimportant, given that these distribution changes have led to serious conflicts between Norway, the Faeroe Island and Iceland (HANNESSON, 2012). In contrast, JANSEN et al. (2012) presented a model of mackerel migration and distribution which, by accounting explicitly for temperature, "holds promise for making projections one-two years into the future" (see also JANSEN et al. (2016); similar results were obtained by BRUGE et al. (2016).

In conclusion, as illustrated here for mackerel Scomber scombrus, we argue that temperature, which is not even listed in the index in the classic on "Fish Migration" HARDEN-JONES (1968), explain far more aspects of fish biology, and particularly of their migrations, than is commonly realized. Indeed, it should be the first driver that is tested when attempting to explain fish distributions and migrations.

\section{ACKNOWLEDGEMENTS}

Daniel PAULY acknowledges support from the SEA AROUND US, a scientific initiative funded by the Paul G. ALLEN Family Foundation, while Çetin KESKIN wishes to thank the Scientific 
and Technological Research Council of Turkey (TÜBITAK) (2219 International Post-Doctoral Research Fellowship Programme). The authors thank Dr Andrés ARAVENA from the Science Faculty at the Istanbul University for extracting the Black Sea SST data used here.

\section{REFERENCES}

BAKUN, A. 2011. The Oxygen constraint. In: V. Christensen and J. Maclean (eds) Ecosystem approaches to fisheries: a global perspective. Cambridge Unversity Press., pp. 11-23.

BOCHDANSKY, A.B. \& W.C., LEGGETT. 2001. Winberg revisited: convergence of routine metabolism in larval and juvenile fish. Can. J. Fish Aquat. Sci., 58: 220-230.

BRUGE, A., ALVAREZ, P., FONTÁN, A., COTANO, U. \& G., CHUST. 2016. Thermal niche tracking and future distribution of Atlantic Mackerel spawning in response to ocean warming. Front. Mar. Sci., doi:10.3389/ fmars.2016.00086.

CHEUNG, W.W.L., WATSON, R. \& D., PAULY. 2013. Signature of ocean warming in global fisheries catch. Nature, 497: 365-368.

CHEUNG, W.W.L., DUNNE, J., SARMIENTO, J. \& D., PAULY. 2011. Integrating eco-physiology and plankton dynamics into projected changes in maximum fisheries catch potential under climate change in the northeast Atlantic. ICES J. Mar. Sci., 68(6): 1008-1018.

CHEUNG, W.W.L., LAM, V.W.Y., SARMIENTO, J.L., KEARNEY, K., WATSON, R., ZELLER, D. \& D., PAULY. 2010. Large-scale redistribution of maximum fisheries catch potential in the global ocean under climate change. Global Change Biol., 16: 24-35.

CHEUNG, W.W.L., LAM, V.W.Y., SARMIENTO, J.L., KEARNEY, K., WATSON, R. \& D., PAULY. 2009. Projecting global marine biodiversity impacts under climate change scenarios. Fish and Fisheries, 10: 235-251.

CIGUÈRE, L.A., CÔTÉ, B. \& J.-F., ST-PIERRE. 1988. Metabolic rates scale isometrically in larval fishes. Mar. Ecol. Prog. Ser., 50: 13-19.

D'AMOURS, D. \& M., CASTONGUAY. 1992. Spring migration of Atlantic mackerel, Scomber scombrus, in relation to water temperature through Cabot Strait (Gulf of St. Lawrence). Environ. Biol. Fishes, 34: 393-399.
DEMIR, M. 1963. Synopsis of biological data on bonito Sarda sarda (Bloch) 1793. FAO Fish. Rep. 6(2), pp. 101-129.

DEMIR, M. 1957. Migrations of Sarda sarda Bloch in the Black, Marmara, and Aegean seas; the probable spawning places and times. GFCM Proc. Tech. Pap., FAO 4, pp. 127-134.

DEMIR, M. \& N., ARIM. 1957. Marmara ve Karadeniz uskumru balığı (Scomber scomber) grubunun üremesi ile alakalı hususlar üzerinde araştırmalar (Investigations on the reproduction of mackerel (Scomber scomber) in the Marmara and Black Seas). Hidrobiyoloji Mecmuası, İstanbul Üniversitesi Fen Fakültesi Hidrobiyoloji Araștırma Enstitüsü Yayınları, A4(1-2): 57-84.

DEMIR, M. \& A., ACARA. 1955. Biological and hydrological factors controlling the migrations of mackerel from the Black Sea to the Sea of Marmara. GFCM Proc. Tech. Rap., 3(41), pp. 365-76.

GALTSOFF, P.S. 1924. Seasonal migrations of mackerel in the Black Sea. Ecology, 5(1):1-5.

GREGG, M.C. \& E., ÖZSOY. 2002. Flow, water mass changes, and hydraulics in the Bosphorus. J. Geophy. Res.: Oceans, 107(C3), 23 pp.

HANNESSON, R. 2012. Sharing the Northeast Atlantic mackerel. ICES J. Mar. Sci.: Journal du Conseil, doi: 10.1093/icesjms/fss134.

HARDEN-JONES, F.R. 1968. Fish Migrations. Edward Arnold, London, 325 pp.

HEAPE, W. 1931. Emigration, migration and nomadism. W. Heffer and Sons, Cambridge, $342 \mathrm{pp}$.

HUGHES, G.M. 1966. The dimensions of fish gills in relation to their function. J. Exp. Biol., 45: 177-195.

IVANOV, L. \& R.J.H., BEVERTON. 1985. The fisheries resources of the Mediterranean. 2. Black Sea. GFCM Studies and Reviews, /FAO, 60, $135 \mathrm{pp}$. 
JANSEN, T., CAMPBELL, A., KELLY, C., HÁTÚN, H. \& M.R., PAYNE. 2012. Migration and Fisheries of North East Atlantic Mackerel (Scomber scombrus) in Autumn and Winter. PLoS ONE, 7(12): e51541. doi:10.1371/journal. pone.0051541

JANSEN, T. \& H., GISLASON. 2011. Temperature affects the timing of spawning and migration of North Sea mackerel. Cont. Shelf. Res., 31: 64-72.

JANSEN, T., POST, S., KRISTIANSEN, T., ÓSKARSON, G.J., BOJE, J, MACKENZIE, B.R., BROBERG, M. \& H. SIEGSTAD. 2016. Ocean warmings expands habitat of a rich natural resource and benefits a national economy. Ecological Applications 26: 2021-2032. doi:10.1002/ eap. 1384

NALBANTOGLU, U. 1957. Contents of the stomachs of mackerel (Scomber scomber L.) caught in the Marmara, the Bosphorus and in the areas of the Black Sea bordering the Bosphorus. GFCM Proc. Tech. Pap., FAO, Rome, No 4, pp. 181-192.

NØTTESTAD, L., GISKE, J., HOLST, J.C. \& G., HUSE.1999. A length-based hypothesis for feeding migrations in pelagic fish. Can. J. Fish Aquat. Sci., 56(S1): 26-34.

NÜMANN, W. 1957. Results of marking experiments on short finned tunas and mackerels in Turkish waters. GFCM Proc. Tech. Pap, FAO, Rome, No 8, pp. 69-74.

PAULY, D. 2010. Gasping Fish and Panting Squids: Oxygen, Temperature and the Growth of Water-Breathing Animals. Excellence in Ecology (22), International Ecology Institute, Oldendorf/Luhe, Germany, xxviii + $216 \mathrm{pp}$.

PAULY, D. 1998. Tropical fishes: patterns and propensities. In: T.E. Langford, J. Langford and J.E. Thorpe (eds.) Tropical Fish Biology. J. Fish Biol., 53 (Supplement A): 1-17.
PAULY, D. 1984. A mechanism for the juvenile-toadult transition in fishes. J. Cons. perm. into Explor. Mer, 41: 280-284.

PAULY, D. 1981. The relationships between gill surface area and growth performance in fish: a generalization of von Bertalanffy's theory of growth. Ber. Deut. Wiss. Komm., 28(4): 251-282.

PEKTAS, H. 1954. Uskumruların muhtemel muhaceret sebepleri ve bu konuda muhit suhunetinin rolü [The role of temperature among the causes for the migration of mackerel]. Hidrobiyoloji Mecmuas1, İstanbul Üniversitesi Fen Fakültesi Hidrobiyoloji Araştırma Enstitüsü Yayınlar1, A2(3): 113-121.

PERRY, A.L., LOW, P.J., ELLIS, J.R. \& J.D., REYNOLDS. 2005. Climate change and distribution shifts in marine fishes. Science, 308(5730): 1912-1915.

ROSE, G.A. 1993. Cod spawning on a migration highway in the north-west Atlantic. Nature, 366(6454): 458-61.

SARHAGE, D. \& J., LUNBECK. 1992. A history of fishing. Springer Verlag, Berlin, Germany, 348 pp.

ULMAN, A. \& D., PAULY. 2016. Making history count: The shifting baselines of Turkish fisheries. Fisheries Research, 183: 74-79.

VİLLAMOR, B., ABAUNZA, P. \& A.C., FARİ̃̃A. 2004. Growth variability of mackerel (Scomber scombrus) off north and northwest Spain and a comparative review of the growth patterns in the northeast Atlantic. Fisheries Research, 69: 107-121

WALSH, M., REID, D.G. \& W.R., TURRELL. 1995. Understanding mackerel migration off Scotland: Tracking with echosounders and commercial data, and including environmental correlates and behaviour. ICES J. mar. Sci., 52: 925-939. 


\title{
Temperaturna ograničenja u oblikovanju migracijskih puteva skuše (Scomber scombrus) u Crnom moru
}

\author{
Daniel PAULY i Çetin KESKIN* \\ "Kontakte-adresa: seahorse@istanbul.edu.tr
}

\begin{abstract}
SAŽETAK
Konvencionalna literatura objašnjava migracije riba u smislu bioloških potreba (hrane, razmnožavanja, staništa, itd.) pri odgovarajućim temperaturama. U ovom radu pomoću primjera (komercijalno nestalih) zaliha crnomorske skuše (Scomber scombrus) navodimo da se sezonske migracije pokreću sezonskim temperaturnim ciklusima. Stoga, temperatura djeluje kao ograničenje određivanja gdje riba može biti u bilo kojem trenutku, a ne kao jedan od nekoliko čimbenika koje bi se razmotrili prilikom odabira između alternativnih putova migracije. Općenito, predlažemo da temperatura uglavnom bude eksplicitan dio hipoteza o migracijskom ponašanju morskih riba.

Za ilustraciju onoga što se može dogoditi kada to nije slučaj, predlaže se da nerazmatranje temperature u modelu migracije sjevernoatlantske skuše, prema mišljenju znanstvenika, može dovesti do osjećaja zadovoljnosti s obzirom na promjene klime prouzročene klimatskim promjenama u fenologiji ove ribe u Sjevernom Atlantiku čija se raspodjela i migracija pogrešno smatra kao "stohastička".
\end{abstract}

Ključne riječi: riba, globalno zatopljenje, raspodjela, potreba za kisikom 